\title{
IMPLEMENTASI DAN EVALUASI CORPORATE SOSIAL RESPONSIBILITY (CSR) DI PERUSAHAAN PENGEBORAN MINYAK PETROCINA KABUPATEN BOJONEGORO - JAWA TIMUR
}

\author{
Sukriyah Kustanti Moerad*
}

\begin{abstract}
Abstrak
Pada dasarnya Corporate Social Responsibility (CSR) membawa misi organisasi dan panduan untuk berdirinya suatu perusahaan yang menjujung tinggi kepada para konsumennya. Perusahaan-perusahaan mulai menerapkan etika bisnis yang merupakan salah satu bentuk bisnis yang memperhatikan Pembangunan Berkelanjutan yang menekankan pada sinergi antara tiga aspek yakni aspek lingkungan hidup, aspek keuangan serta aspek sosial yang dikenal oleh perusahaan-perusahaan dengan sebutan Triple bottom line. JOB Pertamina PetroChina East Java yang berada di Kabupaten Bojonegoro ini adalah Perusahaan Penanam modal asing yang bergerak pada kegiatan pemboran dalam rangka eksplorasi sumur minyak yang dilaksanakan mulai Juni 2007 hingga saat ini. Perusahaan ini sudah melaksanakan kajian lingkungan yang diharuskan oleh Lembaga Lingkungan Hidup. Oleh karena itu peneliti ingin melihat dampak dari penerapan etika sosial ekonomi yang sudah dilaksanakan selama ini. Permasalahan penelitian melihat sejauh mana implementasi dan evaluasi program CSR yang sudah dilaksanakan oleh perusahaan ini. Manfaat penelitian adalah bisa digunakan sebagai data base pemerintah dalam hal etika bisnis perusahaan serta untuk mengukur kinerja perusahaan petrocina dalam melaksanakan nilai-nilai sosial ekonomi pada masyarakat. Hasil penelitian Corporate Sosial Responsibility (CSR) JOB Pertamina - PetroChina East Java, yang sudah dilaksanakan sejak dilaksanakannya kegiatan pemboran di lapangan Sukowati, sebagai tanggung jawab sosial perusahaan dalam menejemen lingkungan hidup. Bentuk/wujud dari Corporate Sosial Responsibility (CSR) yang dilaksanakan JOB Pertamina-Petro Cina adalah pemberian tali asih, dana Community Development serta perekrutan tenaga kerja masyarakat lokal dalam perusahaan tersebut. Evaluasi terhadap pelaksanaan Corporate Sosial Responsibility (CSR), tidak ada aspek kecenderungan kritis seperti sikap aksi protes dan demo masyarakat.
\end{abstract}

Kata kunci : CSR, pembangunan berkelanjutan, pengelolaan, pemantauan, sosialisasi, etika, perusahaan.

Pada era abad 21 yakni tahun 1980 an dan 1990 an, adalah era perusahaanperusahaan mulai menerapkan etika bisnis yang merupakan salah satu bentuk etika terapan dari prinsip-prinsip etis dan moral dalam lingkungan perusahaan. Banyaknya masyarakat yang meminta perusahaan-perusahaan sewajarnya menerapkan tindakantindakan yang normative dan deskriptif. Corporate Sosial Responsibility (CSR) adalah salah satu bentuk tanggung jawab sosial ekonomi suatu perusahaan. Pada dasarnya CSR adalah berguna untuk banyuan kepada misi organisasi serta panduan 
untuk berdirinya suatu perusahaan yang menjujung tinggi kepada para konsumennya.

Konsep tanggung jawab sosial Perusahaan telah dikenal sejak awal 1970, yang secara umum diartikan sebagai kumpulan kebijakan dan praktik yang berhubungan dengan stakeholder, nilai-nilai, pemenuhan ketentuan hukum, penghargaan masyarakat, dan lingkungan hidup, serta komitmen dunia usaha untuk berkontribusi dalam pembangunan secara berkelanjutan (Salim, 2009). Lebih lanjut dikatakan oleh Soerjani (2008), pada dasarnya Pembangunan Berkelanjutan adalah sinergi antara tiga aspek yakni aspek lingkungan hidup, aspek keuangan serta aspek sosial yang dikenal oleh perusahaan-perusahaan dengan sebutan Triple bottom line. Sehingga dunia usaha tidak lagi memperhatikan catatan keuangan perusahaan semata atau biasa disebut single bottom line namun juga mempunyai perhatian terhadap lingkungan sosial masyarakat.

Menurut Muhammad Yunus (2011), bahwa dalam teori pemerintah harus mewakili semua orang dan oleh sebab itu harus memikul tanggung jawab utama dalam mengatasi masalah-masalah sosial yang dapat menimbulkan penderitaan manusia. Di negara-negara beruntung ini terlaksana dengan kadar yang berbedabeda. Akan tetapi pada prateknya pemerintah sering menjadi korban kepentingankepentingan tertentu, partai-partai politik yang mementingkan diri sendiri dan individu-individu yang korup. Demikian pula untuk bisnis sosial, di negara-negara baik negara miskin maupun negara kaya masalah-masalah sosial terus menyusahkan masyarakat manusia, ketergantungan pada sumbangan, pengangguran, kejahatan, kurangnya pemahaman dan pelayanan kesehatan, kerusakan lingkungan yang parah, dan lain sebagainya.

Sesuai dengan Undang-Undang Perseroan Terbatas (UUPT) isi pasal 74 yang baru disyahkan dalam sidang paripurna DPR bahwa, dalam rangka Pemberdayaan Sosial suatu perusahaan, terdapat Program CSR (Program Corporate Social Reponsibility). Program ini merupakan salah satu kewajiban yang harus dilaksanakan oleh setiap perusahaan, industri atau yang sejenisnya yang bergerak di bidang peningkatan pembangunan. Lebih lanjut dikatakan bahwa, sifat dari program

\footnotetext{
* Dosen UPM Soshum ITS
} 
ini tidak memberatkan perusahaan atau industri namun, masih bersifat solidaritas kekeluargaan. Sehingga pembangunan suatu negara bukan hanya tanggung jawab pemerintah dan industri saja, tetapi juga setiap insan manusia berperan aktif untuk mewujudkan tujuan nasional tersebut, yakni kesejahteraan sosial dan pengelolaan kualitas hidup masyarakat. Karena setiap Industri atau sejenisnya berperan untuk mendorong pertumbuhan ekonomi yang sehat dan dengan mempertimbangkan pula faktor lingkungan hidup (Vincent Gaspersz, 2005).

Lebih lanjut dalam pengertian Undang Undang Lingkungan Hidup Nomor 32 tahun 1999 bahwa pada dasarnya pengelolaan lingkungan adalah upaya sadar manusia untuk meningkatkan kesejahteraan rakyat yakni memaksimalkan dampak positif dan meminimalkan dampak negatif sekecil-kecilnya. Kualitas lingkungan yang bersih, sehat dan sejahtera adalah hak semua manusia. Oleh karena itu bagi dunia industri atau perusahaan yang banyak berkecimpung dengan alam lingkungan hidup harus mengupayakan pengelolaan lingkungan hidup yang tetap lestari dan berkesinambungan. Sehingga dapat dirasakan oleh generasi yang akan datang.

Program Corporate Social Reponsibility (CSR) tidak hanya merupakan kegiatan kreatif perusahaan dan tidak terbatas hanya pada pemenuhan aturan hukum semata, namun merupakan program suatu citra yang ditimbulkan oleh perusahaan atau industri dalam skala jangka panjang. Karena menurut Departemen Industri masih banyak perusahaan tidak mau menjalankan program-program CSR ini karena dianggap CSR hanya sebagai pengeluaran biaya (Cost Center) saja, dan tidak memberikan hasil secara keuangan dalam jangka pendek.

Dengan demikian, apabila perusahaan melakukan program-program CSR diharapkan keberlanjutan, perusahaan dapat berjalan dengan baik. Oleh karena itu, program CSR lebih tepat apabila digolongkan sebagai investasi dan harus menjadi strategi bisnis dari suatu perusahaan. Istilah CSR pertama kali menyeruak dalam tulisan Social Responsibility of the Businessman tahun 1953. konsep yang digagas Howard Rothmann Browen ini menjawab keresahan dunia bisnis. Belakangan CSR segera diadopsi, karena bisa jadi penawar kesan buruk perusahaan yang

JOB PERTAMINA - PetroChina East Java adalah Perusahaan Penanam modal asing yang bergerak pada kegiatan pemboran dalam rangka eksplorasi sumur 
minyak yang dilaksanakan mulai Juni 2007 hingga saat ini. Alat pemboran yang digunakan adalah Jenis rig berkemampuan 800 HP dengan sistem pemboran putar/rotary drilling yang dilengkapi dengan peralatan pendukung lain seperti pompa lumpur, peralatan pengendali dan pencegahan sembur liar (BOP), electric wire line logging, air compressor, cementing unit, porta-camp dan kendaraan dan alat - alat berat. Lumpur bor yang digunakan adalah lumpur berbahan dasar air (water base mud/WBM). Selama pemboran tidak digunakan Lumpur berbahan dasar minyak sintetis (oil based mud/OBM). Perusahaan ini telah dilengkapi dengan studi-studi lingkungan yang diwajibkan oleh pemerintah Kementrian Lingkungan hidup, yakni diantaranya kajian AMDAL, Upaya Pengelolaan Lingkungan (UKL) dan Upaya Pemantauan Lingkungan (UPL). Namun demikian masih juga terlihat adanya aksi-aksi ketegangan yang menunjukan ketidak puasan masyarakat sekitar perusahaan tersebut terhadap kehadirannya. Sesuai dengan tujuan Corporate Social responsibility (CSR) yang sudah merupakan kewajiban perusahaan maka penelitian ini mengajukan permasalahan Sehingga akan didapatkan manfaat yang didapat dari penelitian ini adalah citra perusahaan dalam aspek keuangan dan sosial baik dalam jangka pendek maupun dalam jangka panjang.

Tujuan penelitian secara umum adalah melihat sejauh mana suatu perusahaan JOB Pertamina (Petrocina) memaksimalkan tanggung jawab sosialekonomi dalam hal etika bisnis perusahaan. Sedangkan manfaat penelitian ini secara umum bisa digunakan sebagai data base pemerintah dalam hal etika bisnis perusahaan serta tanggung jawab sosial ekonomi. Sedangkan manfaat khusus adalah untuk mengukur kinerja perusahaan petrocina dalam melaksanakan nilai-nilai sosial ekonomi pada masyarakat.

Permasalahan dari penelitian ini adalah sejauh mana kegiatan sosial ekonomi kemasyarakatan yang sudah dilaksanakan oleh perusahaan JOB-Pertamina (petro Cina) tersebut.

\section{Metodologi Penelitian}

Metodologi Penelitian adalah penelitian survei dan observasi lapangan. Populasi adalah masyarakat yang berada di sekitar pengeboran minyak Petrocina yang 
tepatnya berada di Kabupaten Bojonegoro, di Desa Ngampel dan desa Sambiroto Kecamatan Ngampel dan Desa Campurrejo Kecamatan Bojonegoro. Penarikan sampel secara acak random sampling pada sejumlah 50 orang responden. Pengolahan data dengan tabulasi freqwensi sedangkan Analisa data secara deskriptif dengan mencocockan data-data primer (bukti-bukti) yang dimiliki perusahaan petrocina.

\section{Hasil Penelitian}

Sejumlah 50 orang responden secara random sampling yang berhasil kami wawancarai di lokasi penelitian yakni di desa Campurejo kecamatan Bojonegoro dan desa Ngampel, desa Sambiroto, Kecamatan Kapas Kabupaten Bojonegoro diuraikan sebagai berikut. Penerapan Corporate Sosial responsibility meliputi 2 (dua) hal yakni aspek implementasi yakni aspek pengelolaan dan aspek evaluasi dari penerapan tersebut. Hasil penelitian yang didapatkan sebagai berikut dalam uraian dibawah ini.

I. Pengelolaan terhadap Aspek Sosial, Ekonomi pada masyarakat

\section{A. Pengelolaan Persepsi dan Sikap masyarakat}

Sejak didirikannya kegiatan penngeboran minyak di wilayah ini dampak sosial yang muncul dan sifatnya cukup tinggi adalah dampak Persepsi Negatif masyarakat terhadap keberadaan pengeboran minyak ini. Adapun Pengelolaan terhadap Persepsi Negatif yang muncul dari masyarakat sekitar pengeboran minyak yakni keresahan perasaan masyarakat khawatir akan terjadi pencemaran lingkungan yang jelek, yang bisa mengakibatkan kawasan desa rusak. Sehingga diperlukan adanya suatu pengelolaan terhadap hal tersebut. Adapun Upaya Pengelolaan yang sudah dilakukan oleh perusahaan JOB Pertamina (Petro Cina) ini adalah sebagai berikut :

1). Melakukan koordinasi dengan aparat desa Ngampel, Sambiroto, dan Desa Campurejo untuk kegiatan sosialisasi.

2). Melakukan sosialisasi tentang Pengembangan Sumur Sukowati (SKW) termasuk jadwal dan kemungkinan dampak yang diterima masyarakat secara simultan dan berkala secara komunikatif dan difahami oleh masyarakat. 
3). Mengupayakan dana community development dan dilaksanakan secara transparant

4). Pemberian tali asih kepada masyarakat sebelum kegiatan dimulai

5). Mengadakan sosialisasi system tanggap darurat jika terjadi hal-hal yang tidak diinginkan

6). Pembuatan Bangunan penghalang dengan tinggi 2,5 meter untuk menanggulangi kebisingan dari mesin pengeboran

7). Mengutamakan Tenaga kerja lokal sesuai dengan kualifikasi yang dibutuhkan

Untuk pelaksanaan Pengelolaan Persepsi negatif tersebut diatas, maka dilakukan sosialisasi kegiatan dengan tujuan agar masyarakat lebih memahami dan menerima kegiatan yang dimaksudkan. Adapun pelaksanaan sosialisasi terhadap masyarakat dilaksanakan di 3 desa terkait yakni desa Campurejo Kecamatan Bojonegoro, dan Desa Ngampel dan Sambiroto Kecamatan Kapas Kabupaten Bojonegoro yang dilakukan secara bertahap, sebagai berikut:

1). Sosialisasi Kegiatan I, dilaksanakan di Balai Desa Ngampel pada hari Sabtu, tanggal 20 September 2008 pada pukul 15.00 - 18.00. Sebelum kegiatan sosialisasi ini dimulai pihak JOB Pertamina terlebih dulu berkoordinasi dengan pihak terkait yakni Pemda (Tim PKDB, Infokom, Bagian Pengendalian Dampak Lingkungan) dan aparat Desa. Kegiatan ini dihadiri oleh Bapak Camat Kapas sekaligus sebagai Moderator, dan Bapak ketua Bagian Pengendalian Lingkungan Hidup Bojonegoro, Bapak Lurah Ngampel, beserta aparat Desa Ngampel dan Sambiroto serta Bapak Danramil, dan peserta sosialisasi yaitu masyarakat Desa Ngampel dan Desa Sambiroto, sejumlah 179 orang. Sedangkan Pihak JOB Petrocina yang hadir berjumlah 6 orang. Acara Sosialisasi ditutup pada pukul 17.30 dengan acara Buka Puasa bersama.

2). Sosialisasi Kegiatan II, dilaksanakan di Balai Desa Campurrejo pada hari Senin, anggal 22 September 2008 pada pukul 15.00 - 18.00. Seperti halnya pada kegiatan sosialisasi di Desa Ngampel, pada kegiatan sosialisasi di Desa Campurrejo juga sebelum kegiatan sosialisasi ini dilaksanakan pihak JOB PPEJ Petrocina terlebih dulu berkoordinasi dengan pihak terkait yakni Pemda (Tim PKDB, Infokom, Bagian Pengendalian Dampak Lingkungan) dan aparat Desa 
Dihadiri oleh Muspika; Bapak ketua Bagian Pengendalian Lingkungan Hidup Bojonegoro,LPMD; Kepala Desa terkait, RT dan RW; karang taruna; masyarakat, Tokoh masyarakat dengan jumlah peserta 155 orang. Sedangkan Pihak Petrocina yang hadir berjumlah 7 orang. Acara Sosialisasi ditutup pada pukul 17.30 dengan acara Buka Puasa bersama.

B. Pemberian Tali asih

Pada kegiatan Pemboran sumur yakni selama ada kegiatan pemboran di Sukawati (SKW), di dalam pengelolaannya ada kegiatan pemberian tali asih dilaksanakan oleh pihak perusahaan JOB Pertamina Adapun tali asih yang dilaksanakan pada bulan Oktober-November 2008 terhitung mulai tanggal 3 Oktober 2008 hingga tanggal 3 Maret 2009, tersebut berupa inkid (sembako) senilai Rp. 120.000.000,- (seratus dua puluh juta rupiah). Kepada tiga (3) desa di sekitar lokasi Sukowati yakni desa Ngampel, Desa Sambiroto Kecamatan Kapas, dan Desa Campurejo Kecamatan Bojonegoro). Tali Asih tersebut diterimakan kepada Kepala Desa dengan rincian yang berbeda sebagai berikut.

Tabel 1: Nama dan Jabatan Penerima Tali Asih

\begin{tabular}{|c|l|l|c|}
\hline No & \multicolumn{1}{|c|}{ Nama penerima } & \multicolumn{1}{c|}{ Jabatan } & Jumlah ( Rp.) \\
\hline 1 & Budi utomo & $\begin{array}{l}\text { Kepala Desa } \\
\text { Campurrejo }\end{array}$ & 44.928 .000 \\
\hline 2 & Sri Utami & Kepala Desa Sambiroto & 23.232 .000 \\
\hline 3 & Pudjianto & Kepala Desa Ngampel & 11.840 .000 \\
\hline 4 & Pujianto Jumlah & Kepala Desa Ngampel & 40.000 .000 \\
\hline \multicolumn{2}{|c|}{ Jum } & 120.000 .000 \\
\hline
\end{tabular}

Sumber : Data sekunder, Petrocina

Pemberian tali asih ini masih dikukan pada nomor 4 tabel diatas yakni pada tanggal 4 Maret 2009 di Desa Ngampel sejumlah tersebut diatas yang berupa Sembako dengan disaksikan oleh 7 orang ketua RT. Desa Ngampel Kecamatan Kapas.

C. Pemberian dana Community Development

Pemberian dana community Development yang sudah dilaksanakan oleh pihak JOB Pertamina, menurut masyarakat (hasil wawancara dengan responden) di desa Ngampel, Sambiroto dan Campurrejo dengan jumlah responden 50 orang, sejumlah 
16 responden (32\%) menyatakan bahwa dana community development digunakan untuk pembangunan Balai desa, dan 12 responden (24\%) menyatakan untuk pembangunan kantor desa, pembuatan jalan lingkungan, untuk masjid, dan untuk pembersihan saluran air, dan 11 responden (22\%) menyatakan dana community development digunakan untuk pembangunan Desa, dan 8 responden (16\%) menyatakan bahwa dana community development digunakan untuk pembelian pupuk untuk petani, pembelian hewan ternak, dan pembangunan balai RW dan Polindes serta $3(6 \%)$ responden lainnya menyatakan bahwa dana community development tersebut adalah bantuan dana bergulir untuk pembangunan desa. Dalam tabel dibawah point nomor 11 dana Community development tersebut digunakan untuk Pembiayaan Program Penghijauan di wilayah Campurejo dan Pengadaan Lampu PJU. Adapun realisasi pernyataan responden tersebut kami sajikan dalam tabel di bawah ini. 
Tabel 2 : Bantuan Program Community Development untuk pengeboran minyak (SKW)

\begin{tabular}{|c|c|c|c|c|c|}
\hline \multirow[t]{2}{*}{ No } & \multirow{2}{*}{$\begin{array}{l}\text { Tanggal } \\
\text { Penyerahan }\end{array}$} & \multicolumn{3}{|c|}{ Penerima } & \multirow{2}{*}{$\begin{array}{r}\text { Jumlah } \\
\text { ( Rp. ) }\end{array}$} \\
\hline & & Nama & Jabatan dan Institusi & Desa & \\
\hline 1 & 6 Oktober 2008 & $\begin{array}{l}\text { Nunuk Aries } \\
\text { Auliyaur Rokhim }\end{array}$ & $\begin{array}{l}\text { Ketua, PAUD Tunas Bangsa } \\
\text { Ketua, TPA Baitur Rahmat }\end{array}$ & Campurejo & 6.800 .000 \\
\hline 2 & 28 Oktober 2008 & $\begin{array}{l}\text { Nunuk Aries } \\
\text { Lailatul Musyafa'ah } \\
\text { Sutji Rochani } \\
\text { Lailatul Musyafa'ah }\end{array}$ & $\begin{array}{l}\text { Ketua, PAUD Tunas Bangsa } \\
\text { Kep. Sekolah RA Mahbaul } \\
\text { Ulum } \\
\text { Kep.Sekolah TK Putra Bangsa } \\
\text { Kep.Sekolah KB Manbaul Ulum }\end{array}$ & Campurejo & 14.900 .000 \\
\hline 3 & 6 Nopember 2009 & $\begin{array}{l}\text { Endah Susilowati, Sutari, } \\
\text { Sutji R Ilham Soliq, Lailatul } \\
\text { M, Auliyaur R, A. Nafi'I, } \\
\text { Ach Syukur, M Ridwan, Nur } \\
\text { Sidig, M.Rasmadi, Masirat, } \\
\text { Zainuddin, Muchid Husni, M } \\
\text { Muhazir. }\end{array}$ & $\begin{array}{l}\text { Kep.Sekolah RA Mahbaul } \\
\text { Ulum, TK Alquar'an, } \\
\text { MIMahbaul Ulum, SDN } \\
\text { Campurejo II, SDN Campurejo } \\
\text { I, , TK Putra Bangsa, }\end{array}$ & Campurrejo & 52.640 .000 \\
\hline 4 & 12 Nopember 2009 & Anik Suyanti & Ketua TPA Al-Mubarok & Campurejo & 1.360 .000 \\
\hline 5 & 3 Desember 2009 & Sudargo & Ketua KUB Sejati & Ngampel & 34.980 .000 \\
\hline 6 & 11 Desember 2009 & Budi Utomo & Kepala Desa & Campurejo & 100.000 .000 \\
\hline 7 & 16 Desember 2009 & Sutini & $\begin{array}{l}\text { Kepala Sekolah SDN Sambiroto } \\
\text { I }\end{array}$ & Sambiroto & 19.000 .000 \\
\hline 8 & 18 Desember 2009 & $\begin{array}{l}\text { Mulyati, Kastari, Tri Imanik, } \\
\text { Achmad Jumain, Sri } \\
\text { Wahyuni, Rostaminto, Didik } \\
\text { Santoso, Parmi, Bambang } \\
\text { Priyono, Lilik Zumaroh }\end{array}$ & $\begin{array}{l}\text { Ketua: KUD Anggrek, KUD } \\
\text { Tika Jaya,KUD Cantika Flores, } \\
\text { KUD Minak Jinggo, KUD } \\
\text { Katering Wahyu,KUD Bunga } \\
\text { Malam, KUD Melati Putih,KUD } \\
\text { Aneka Kue, KUD Barokah, } \\
\text { KUD Manteh Rasa. }\end{array}$ & Campurejo & 53.000 .000 \\
\hline 9 & 24 Desember 2009 & $\begin{array}{l}\text { Ery Agustina,Hartono Neng } \\
\text { Setyo,Sulasrti, Eko Yudo, } \\
\text { Sutono, Jupri, Sukahar, } \\
\text { Nadhim, Damtono, Sukoco }\end{array}$ & $\begin{array}{l}\text { Kep. Sekolah SDN Mulyoagung } \\
\text { 2, Ketua KUD Krupuk Krapyak, } \\
\text { KUD Mawar Berduri, KUD } \\
\text { Mawar, KUD Lembu Mulya, } \\
\text { KUD Sumber Urip, KUD } \\
\text { Sejahtera Mandiri, KUD Damar } \\
\text { Wulan, KUD Giling Tepung, } \\
\text { KUD Margo Agung, KUD Jati } \\
\text { Mulya. }\end{array}$ & Campurejo & 118.000 .000 \\
\hline 10 & 29 Desember 2008 & $\begin{array}{l}\text { Hariyono, Alim Sugiono, } \\
\text { Sukadi, Setyoko, M. Ridwan }\end{array}$ & $\begin{array}{l}\text { Ketua KUD Creatif Com, KUD } \\
\text { Las Nusa Bakti, KUD Hippa } \\
\text { Mandiri, KUD Plosolanang, } \\
\text { KUD Gapoktan Manunggal } \\
\text { Sejati. }\end{array}$ & Campurejo & 84.000 .000 \\
\hline 11 & 21 Januari 2009 & Damtono & Ketua Tim Lak Lingkungan & Campurejo & 26.000 .000 \\
\hline
\end{tabular}

Sumber : Data sekunder, Petrocina 


\section{Pengelolaan terhadap Peluang Kerja/kesempatan kerja}

Pengelolaan dampak terhadap peluang kerja yang sudah dilakukan adalah rekruitmen tenaga kerja dengan cara kerjasama antara aparat desa setempat dan pihak JOB Pertamina (Petro Cina) dan kontraktor. Dalam pengelolaan ini ada suatu komitmen antara pihak JOB Pertamina dengan aparat desa di wilayah penelitian untuk membahas proporsi rekruitmen tenaga kerja dari kegiatan pemboran sumur di sekitar lokasi pemboran minyak. Dilakukan diskusi antara pihak JOB Pertamina (Petrocina) dan perangkat desa terkait. Dari hasil diskusi tersebut diperoleh kesepakatan bahwa jumlah tenaga kerja yang dibutuhkan ada 177 orang dengan proporsi rekruitmen tenaga kerja diambil 104 orang $(58,75 \%)$ dari desa Ngampel, $20(11,29 \%)$ orang dari Desa Sambiroto dan $53(29,96 \%)$ orang dari Desa Campurrejo. Adapun Jumlah tenaga kerja yang dibutuhkan diumumkan secara terbuka sesuai dengan kualifikasi dan kebutuhan secara transparan. Total tenaga kerja lokal di wilayah penelitian yang terlibat dalam kegiatan tersebut terinci dalam tabel dibawah ini :

Tabel 3: Posisi Dan Jumlah Tenaga Kerja Lokal Yang Terlibat Dalam Kegiatan

\begin{tabular}{|c|c|c|}
\hline No & Posisi & Jumlah \\
\hline 1. & Environment & 24 orang \\
\hline 2. & Watchman & 77 orang \\
\hline 3. & Sweeper & 76 orang \\
\hline 4. & Total & 177 orang \\
\hline
\end{tabular}

Sumber : Data Sekunder, Petrocina.

Adapun kesepakatan kerja ini yang diterima ini tertuang dalam Surat kesepakatan bersama dan agreement dengan pihak outsourcing tenaga tenaga kerja dan karyawan yang diterima.

II. Evaluasi

Evaluasi dalam penelitian diartikan sebagai hasil penerapan pengelolaan yang menyangkut evaluasi pengelolaan sosial ekonomi budaya, evaluasi tingkat kritisisasi masyarakat serta evaluasi pentaatan dampak secara legal formal. 


\section{A. Evaluasi terhadap pengelolaan Sosial Ekonomi Budaya}

Di Tiga (3) desa sekitar lokasi sumur pengeboran yakni Desa Campurejo, Desa Ngampel dan Desa Sambiroto, semua responden mengatakan bahwa sudah pernah dilakukan sosialisasi. Frekuensi dari sosialisasi berbeda-beda antara desa satu dengan desa yang lainnya. Pelaksanaan sosialisasi diadakan di balai desa yang dihadiri oleh Tokoh masyarakat, perangkat Kecamatan dan desa, masyarakat desa terkait di masing-masing desa, dan pihak Bagian Lingkungan Hidup Kabupaten bojonegoro. Penyelenggara sosialisasi adalah pihak JOB Pertamina (Petro Cina) yang dibantu oleh Bapak Camat Kapas dan Camat Bojonegoro. Hasil Sosialisasi tahap I yakni di Balai Desa Ngampel, Ketika sosialisasi berlangsung, tidak terdapat penolakan terhadap rencana kegiatan. Pada umumnya masyarakat memahami dan menerima tentang rencana tersebut. Hal-hal yang menjadi perhatian masyarakat adalah sebagai berikut :

a. Merealisasikan perbaikan jalan menuju lokasi Lapangan Sukowati

b. Merealisaisikan pembangunan tembok/pagar pembatas dan penanaman bambu sebagai barrier untuk mencegah timbulnya kebisingan hingga saat sosialisasi belum terealisasi

c. Keterlibatan masyarakat dalam kegiatan sebagai tenaga kerja tetap maupun tidak tetap sesuai dengan keahlian dan kebutuhan.

d. Memberikan kompensasi jika terjadi kerusakan atau bahaya lingkungan

e. Tetap melakukan penyediaan air bersih bagi masyarakat sekitar

Penyampaian keluhan masyarakat ini dengan cara melaporkan kepada tokoh masyarakat di desa tersebut. Sedangkan tokoh masyarakat menyampaikan keluhan masyarakatnya kepada pihak JOB Pertamina (Petro Cina), untuk segera mendapat tanggapan dan penyelesaian. Salah satu cara yang dilakukan untuk menyelesaikan keluhan dari masyarakat adalah dengan mengadakan rembug desa untuk membahas permasalahan yang ada dan bagaimana solusinya.

Sebanyak $19(55,89 \%)$ responden menyatakan bahwa, kegiatan pemboran sumur Sukowati \#9 dan \#10, untuk desa Ngampel, Keuntungan dari adanya 
pemboran sumur adalah adanya penyerapan tenaga kerja yang dipekerjakan sebagai tenaga petugas lapangan, petugas satpam. Sedangkan peningkatan kenyamanan adalah penerangan jalan di desa Ngampel yakni adanya bantuan Pengadaan lampu PJU senilai Rp. 14.850.815,00.

Sedangkan ada beberapa kerugian yang dirasakan oleh responden diantaranya jalan-jalan menjadi rusak dan berdebu pada masa Konstruksi kegiatan. Kerugian lain yang dirasakan responden berkaitan dengan adanya pengeboran sumur adalah adanya kebisingan pada saat proses pengeboran. Dampak terhadap kesehatan menurut responden tidak ada.

\section{A.1 Evaluasi Tingkat Kritis Dampak Persepsi Negatif Masyarakat}

Tingkat kritis masyarakat di wilayah penelitian ini diartikan sebagai aksi dan reaksi terhadap keberadaan perusahaan JOB Pertamina (Petrocina). Sejumlah 46 (92 $\%)$ dari 50 orang responden menyatakan bahwa tingkat reaksi masyarakat tergolong rendah. Sehingga persepsi negatif akibat dampak langsung yang berasal dari Kegiatan pembangunan yang menimbulkan dampak munculnya persepsi negatif masyarakat, dapat diminimalisir. Demikian pula muncul dampak tidak langsung dari kegiatan pengadaan Peralatan pemboran dan adanya penumpukan bahan material untuk pemboran tersebut, serta dari adanya pengoperasian kawasan lapangan pemboran Sukowati untuk sumur \# 9 dan \# 10. Adapun pengaruh yang muncul adalah perasaan kekhawatiran dan keresahan terhadap kebisingan suara mesin pemboran dan kekhawatiran dan keresahan akan terjadi luapan lumpur seperti yang terjadi di Sidoarjo. Adapun Persepsi negatif yang ditimbulkan akibat kegiatan tersebut yaitu berupa keluhan dan kekhawatiran namun relatif tidak besar dan tidak sampai menimbulkan aksi demo/protes dari warga sekitar pemboran.

\section{A.2 Evaluasi Penaatan Dampak persepsi negatif Masyarakat}

Evaluasi pentaatan adalah legal aspek peraturan perundang undangan yang sudah dilaksanakan oleh JOB Pertamina (Petro Cina). Pengelolaan dan pemantauan terhadap persepsi negatif masyarakat pada kegiatan pemboran ini yang ada di lapangan Sukowati telah dilakukan sudah sesuai aturan yang diberlakukan. Adapun aspek legal formal yang sudah dimiliki adalah Dokumen Analisa Mengenai Dampak Lingkungan (AMDAL) serta dokumen UKL - UPL (Upaya Kelola 
Lingkungan dan Upaya Pemantauan Lingkungan) Pemboran Sumur \# 9 dan \# 10 di lapangan Sukowati, Kabupaten Bojonegoro yang disetujui oleh Ditjen Migas.

B. Evaluasi Pengelolaan Dampak Peluang Kerja

B.1. Evaluasi Kecenderungan Dampak Peluang Kerja

Sebanyak $35(70 \%)$ Responden dari sejumlah 50 orang responden menyatakan bahwa salah satu keuntungan yang dirasakan oleh masyarakat berkaitan dengan adanya pemboran yang dilakukan JOB Pertamina (Petro Cina) yakni sumur yang ada di lapangan Sukowati ini adalah adanya peningkatan kesempatan kerja dan penyerapan tenaga kerja lokal. Seperti dalam uraian diatas bahwa Tenaga kerja yang terserap di lokasi desa penelitian sebanyak 177 orang yang tersebar di 3 desa yakni Desa Campurejo, Desa Ngampel dan Desa Sambiroto. Adapun kualifikasi yang dapat diserap oleh tenaga kerja tersebut disajikan dalam bab pelaksanaan peluang tenaga kerja.

\section{B.2. Evaluasi Tingkat Kritis Dampak Peluang Kerja}

Terdapat keluhan warga mengenai adanya perbedaan proporsi rekruitmen tenaga kerja dari tiga (3) desa penelitian. Namun demikian reponden menyatakan bahwa walaupun proses rekruitment tersebut secara terbuka yang pelaksanaannya oleh JOB - Pertamina (Petro Cina) yang banyak mengutamakan tenaga kerja di luar desa penelitian tersebut tetapi yang banyak adalah kota kabupaten Bojonegoro. Disamping kualifikasi yang dibutuhkan masih belum banyak tersedia di desa penelitian lebih banyak ada di kota kabupaten. Apresiasi masyarakat terhadap aktifitas pemboran yang dilakukan menjadi positip, sehingga aksi protes/demo dari masyarakat sekitar terhadap kegiatan yang dilakukan tidak sampai terjadi.

\section{B.3. Evaluasi Penaatan Dampak Peluang Kerja}

Evaluasi terhadap pentaatan secara legal formal pada aspek peluang tenaga kerja. Pentaatan ini menurut aturan yang sudah dituangkan dalam dokumen Analisis Mengenai Dampak Lingkungan dan dokumen Upaya Pengelolaan Lingkungan dan Upaya Pemantauan Lingkungan (UKL-UPL). Adanya kesempatan kerja yang sudah bisa dinikmati oleh desa wilayah penelitian ini seperti data diatas jumlah orang di desa penelitian yang bisa masuk sebagai tenaga kerja di JOB Pertamina (Petro Cina) 
membuktikan bawa pihak perusahaan sudah menerapkan penyerapan tenaga kerja sesuai dengan permintaan masyarakat. Pengelolaan dan pemantauan dampak peluang kerja yang telah dilakukan sesuai dalam Dokumen tersebut untuk Pemboran Sumur \# 9 dan \# 10 di lapangan Sukowati, Kabupaten Bojonegoro telah disetujui oleh Ditjen Migas.

\section{Kesimpulan}

Berdasarkan hasil penelitian diatas dapat kami simpulkan bahwa:

1. Pelaksanaan kegiatan Corporate Sosial Responsibility (CSR) yang ada di Perusahaan JOB Pertamina - Petrocina adalah salah satu kegiatan yang menunjang Pembangunan Yang Berkelanjutan Berwawasan Lingkungan.

2. Corporate Sosial Responsibility (CSR) JOB PERTAMINA - PetroChina East Java, yang sudah dilaksanakan sejak dilaksanakannya kegiatan pemboran di lapangan Sukowati, sebagai tanggung jawab sosial perusahaan dalam menejemen lingkungan hidup

3. Bentuk/wujud dari Corporate Sosial Responsibility (CSR) yang dilaksanakan JOB Pertamina-Petro Cina adalah pemberian tali asih, dana Community Development serta perekrutan tenaga kerja masyarakat lokal dalam perusahaan tersebut.

4. Evaluasi terhadap pelaksanaan Corporate Sosial Responsibility (CSR), tidak ada aspek kecenderungan kritis seperti sikap aksi protes dan demo masyarakat.

Saran untuk kelanjutan pelaksanaan Corporate Sosial Responsibility (CSR) adalah :

Perlakuan terhadap kegiatan CSR harus tetap berlanjut, sustainability, berkesinambungan serta terprogram yang melembaga. 


\section{Daftar Pustaka}

Direktorat Pemberdayaan Masyarakat Pesisir. 2006. Pedoman Umum Pemberdayaan Ekonomi Masyarakat Pesisir. Dirjen Kelautan. Jakarta.

J.Dwi Nurwoko .2006. Sosiologi Teks Pergaulan danTterapan. Jakarta : Kencana Prenada, Media Group.

Muhammad Yunus. 2011. Bisnis Sosial. Sistem Kapitalisme Baru yang Memihak Kaum Miskin. PT. Gramedia Pustaka. Jakarta.

Salim Emil, 2009. Pembangunan Berkelanjutan. Makalah Munas Perwaku. Jakarta.

Soerjani Moch. 1989. Sumberdaya Alam. Pembangunan dan Lingkungan Hidup. Jakarta.

Suharto, Edi. 2005. Membangun Masyarakat Memberdayakan Rakyat. Bandung. PT. Refika Aditama.

Singarimbun, Masri. 1989. Metode Penelitian Survey. LP3ES. Yogyakarta.

Vincent Gaspersz. 2005. Sistem Manajemen Kinerja Terintegrasi. PT. Gramedia Pustaka umum. Jakarta. 